\title{
How Behavioral Finance during Pandemic COVID-19?
}

\author{
Asri Solihat, Nugraha \\ Sekolah Pasca Sarja Universitas Pendidikan Indonesia \\ Jl Dr. Setiabudhi No. 299 Bandung \\ asrisolihat@upi.edu
}

\begin{abstract}
The global pandemic of COVID-19 has created dramatic and unprecedented challenges for individuals, the economy, financial markets, financial institutions and governments. The purpose of this study was to determine how much change in financial behavior during the COVID-19 pandemic. This study uses a literature review method by comparing several previous research findings that are relevant to the COVID-19 pandemic problem. The results of this study reveal changes in financial behavior during the COVID-19 pandemic, especially in urban areas that are in the red zone and many financial transactions.
\end{abstract}

Keywords- Behavioral Finance, Pandemic COVID-19

\section{PENDAHULUAN}

Pandemi global COVID-19 telah menciptakan tantangan dramatis dan belum pernah terjadi sebelumnya bagi individu, ekonomi, pasar keuangan, lembaga keuangan dan pemerintah. Selain biaya manusia yang besar dalam kematian dan penyakit, virus ini telah menimbulkan gangguan ekonomi yang sangat besar di seluruh dunia sebagian disebabkan oleh efeknya sendiri dan sebagian oleh tindakan pemerintah untuk mengendalikan penyebarannya. Pada era ini pengangguran berskala besar dan tiba-tiba serta pengurangan aktivitas ekonomi dan pergerakan harga yang kejam di banyak pasar keuangan dengan skala setidaknya sebanding dengan krisis keuangan sebelumnya. Penelitian ini bertujuan untuk melihat bagaimana wawasan dari keuangan perilaku dapat membantu para peneliti dan pembuat kebijakan untuk memahami pergerakan pasar keuangan dan ekonomi dan tindakan partisipan yang beragam dalam menanggapi krisis Covid-19.

Ketika dampak pandemi COVID-19 terus berkembang di seluruh dunia, ini memengaruhi orang dan komunitas yang berbeda dengan cara yang berbeda. Tetapi satu kesamaan adalah bahwa, di samping kekhawatiran tentang kesehatan mereka sendiri dan kesehatan keluarga, teman-teman dan orang-orang terkasih, orang-orang peduli dengan kesejahteraan finansial mereka. Kekhawatiran ini termasuk bagaimana memenuhi kewajiban sehari-hari seperti sewa atau bahan makanan - dan meluas ke masalah-masalah seperti cara terbaik untuk membayar pajak, cara mengakses uang tunai untuk barang-barang penting, bagaimana melakukan pembayaran digital, cara mendapatkan uang kepada orang-orang yang dicintai, dan bagaimana mengelola investasi. Wabah
COVID-19 yang sedang berlangsung menghasilkan liputan berita yang belum pernah terjadi sebelumnya dan curahan pendapat di era penyebaran informasi yang cepat ini. Ketidakpastian di pasar keuangan menyebabkan peningkatan volatilitas harga, menemukan bahwa kepanikan luar biasa yang ditimbulkan oleh outlet berita terkait dengan peningkatan volatilitas di pasar ekuitas.

\section{KAJIAN PUSTAKA}

Perilaku keuangan penting di tingkat individu maupun perusahaan [1]. Banyak penelitian yang menganalisis Perilaku keuangan perusahaan telah dilakukan dalam beberapa dekade terakhir. Namun semua terkait dengan solusi masalah modal atau pembiayaan utang, menemukan sumber peningkatan modal terbaik atau kemungkinan utang termurah. Perilaku keuangan menggabungkan dampak psikologi dan ilmu ekonomi untuk menemukan yang mendasari alasan untuk solusi irasional pengeluaran investasi, pinjaman dan tabungan. Perilaku keuangan bertentangan dengan salah satu aksioma keuangan konvensional, yang menyatakan bahwa manusia itu rasional, dan membuat semua keputusan keuangan setelah mempertimbangkan semua masalah dengan seksama [2]. Teori ekonomi, menjelaskan keputusan manusia di pasar, mengacu pada motif psikologis. Ahli teori perilaku berpendapat bahwa pengambilan keputusan manusia tidak selalu didasarkan pada bahan atau alasan rasional; Seringkali seseorang hanya mengikuti tradisi tertentu atau mencoba menghindari risiko dan kesulitan [3]. Pendukung teori prospek, dikaitkan dengan teori perilaku, berpendapat bahwa perilaku manusia sering ditentukan oleh keinginan 
konstan untuk menghindari kerugian daripada keinginan untuk menghasilkan pendapatan [4].

Perilaku keuangan penting di tingkat individu maupun perusahaan. Biasanya sebagian besar penelitian perilaku perusahaan terkait dengan struktur modal, penganggaran atau masalah keuangan [5]. Oleh karena itu, Penelitian ini bertujuan untuk menilai fitur pengambilan keputusan entitas non-keuangan ketika mereka beroperasi di pasar keuangan. Perilaku keuangan sedang dibangun sebagai struktur keuangan yang solid [6]. Ini memasukkan bagian-bagian dari keuangan standar, menggantikan yang lain, dan termasuk jembatan antara teori, bukti, dan praktik. Perilaku keuangan menggantikan orang normal dengan orang rasional dalam keuangan standar. Ini menggantikan teori portofolio perilaku untuk teori portofolio mean-variance, dan model penetapan harga aset perilaku untuk CAPM dan model lain di mana pengembalian yang diharapkan hanya ditentukan oleh risiko [1]. Perilaku keuangan juga membedakan pasar rasional dari pasar yang sulit dikalahkan dalam diskusi pasar yang efisien, perbedaan yang sering kabur dalam keuangan standar, dan ia meneliti mengapa begitu banyak investor percaya bahwa mudah mengalahkan pasar. Selain itu, Perilaku keuangan memperluas domain keuangan di luar portofolio, penetapan harga aset, dan efisiensi pasar dan diatur untuk melanjutkan ekspansi tersebut sambil tetap berpegang pada kekakuan ilmiah yang diperkenalkan oleh keuangan standar [7].

Penelitian Jurevičienè et al. pada tahun 2014 [1] mengevaluasi keputusan investasi keuangan perusahaan yang dibuat melalui survei para ahli, mencoba untuk menilai pemain utama di pasar keuangan antara perusahaan non-keuangan, dengan mempertimbangkan pembentukan portofolio, motivasi investasi, hubungan pengembalian risiko, dll. Hasilnya menunjukkan bahwa perusahaan non-keuangan Lithuania tidak terlalu aktif di pasar keuangan; mereka memilih investasi jangka pendek yang kurang berisiko (kurang menguntungkan), menyimpan uang tunai atau deposito berjangka dalam jumlah yang cukup besar, dan berusaha mengumpulkan dana dari investasi keuangan untuk implementasi berbagai proyek yang berkaitan dengan kegiatan utama perusahaan mereka. Umumnya perusahaan jasa, beroperasi selama lebih dari lima tahun dan dengan volume penjualan melebihi 1,45 juta Euro per tahun, adalah pemain utama di pasar keuangan di antara perusahaan nonkeuangan.perusahaan non-keuangan Lithuania tidak terlalu aktif di pasar keuangan; mereka memilih investasi jangka pendek yang kurang berisiko (kurang menguntungkan), menyimpan uang tunai atau deposito berjangka dalam jumlah yang cukup besar, dan berusaha mengumpulkan dana dari investasi keuangan untuk implementasi berbagai proyek yang berkaitan dengan kegiatan utama perusahaan mereka. Umumnya perusahaan jasa, beroperasi selama lebih dari lima tahun dan dengan volume penjualan melebihi 1,45 juta Euro per tahun, adalah pemain utama di pasar keuangan di antara perusahaan non-keuangan [8].

Sementara penelitian Grohmann pada tahun 2018 [3] menganalisis literasi keuangan dan perilaku keuangan orang-orang kelas menengah yang hidup di ekonomi Asia perkotaan. Selain sebagian besar Penelitian tentang literasi keuangan yang berfokus pada orang-orang di negara maju, mensurvei orangorang yang tinggal di Bangkok. Dengan menggunakan pertanyaan literasi keuangan standar, menemukan bahwa tingkat literasi keuangan sebagian besar sebanding dengan negara-negara industri, tetapi pemahaman tentang konsep keuangan yang lebih maju lebih rendah [9]. Demikian pula, rekening tabungan dipegang oleh kebanyakan orang, tetapi produk yang lebih canggih jauh lebih umum. selanjutnya menunjukkan, sejalan dengan literatur, bahwa literasi keuangan yang lebih tinggi mengarah pada pengambilan keputusan keuangan yang lebih baik. Dalam penelitian ini, mempelajari perilaku keuangan dan literasi keuangan kelas menengah perkotaan di Asia. Kelas menengah sudah sering telah diabaikan dalam studi empiris, karena Penelitian tentang literasi keuangan telah melihat populasi di negara industri atau berfokus pada orang miskin yang tinggal di negara berkembang. Ini terlepas dari peran penting yang dimainkan oleh kelas menengah untuk pertumbuhan dan perkembangan. Salah satu alasan mengapa kelas menengah di pasar negara berkembang dianggap penting untuk pertumbuhan adalah kelas menengah memiliki tabungan lebih besar daripada orang miskin, terutama karena kelas menengah cenderung memiliki pekerjaan yang stabil. Dalam hal ini, sangat penting untuk mempelajari literasi keuangan dan pengambilan keputusan keuangan kelas menengah. Pengambilan keputusan keuangan yang baik oleh kelas menengah di negara-negara berkembang mungkin memiliki konsekuensi yang lebih jauh dari pada pengambilan keputusan keuangan oleh orang miskin. Studi pertama yang meneliti dampak melek finansial di kalangan kelas menengah yang tinggal di perkotaan daerah di Asia. Berbeda dengan orang miskin di negara berkembang, sebagian besar anggota kelas menengah, terutama mereka yang tinggal di daerah perkotaan, memiliki akses ke berbagai produk simpanan dan 
saluran pinjaman. Namun, sedikit yang diketahui tentang seberapa efektif kelas menengah menggunakan layanan keuangan ini, dan sejauh mana kurangnya literasi keuangan merupakan hambatan. Dalam tulisan ini pertama kali menunjukkan bahwa tingkat rata-rata literasi keuangan kelas menengah di Bangkok mirip dengan yang dikembangkan negara. Namun, pengetahuan tentang diversifikasi pasar saham masih kurang, dengan hanya $24 \%$ menjawab pertanyaan ini dengan benar. Selain itu, penelitian tersebut dapat menunjukkan bahwa literasi keuangan memiliki dua manfaat utama. Pertama, individu yang melek finansial lebih cenderung memiliki aset selain dari rekening tabungan dan lebih cenderung memiliki rekening deposito tetap. Mereka juga cenderung memiliki asuransi jiwa, yang memberikan pengembalian sangat rendah. Oleh karena itu penelitian ini menunjukkan bahwa responden kelas menengah dengan literasi keuangan yang lebih tinggi lebih cenderung menggunakan berbagai layanan keuangan yang ditawarkan kepada mereka. Kedua, mereka menggunakan kartu kredit dengan cara yang lebih terinformasi: mereka lebih cenderung mengetahui tingkat bunga pada kartu kredit dan lebih sedikit kesulitan melunasi hutang kartu kredit. Akhirnya, hubungan dari literasi keuangan dengan perilaku finansial ini bersifat kausal, seperti yang ditunjukkan melalui regresi IV. Dalam sampel, tidak menemukan dukungan untuk hubungan positif yang diharapkan antara literasi keuangan dan partisipasi pasar saham sering ditemukan di pasar negara maju. Diambil bersama-sama dengan rendahnya pengetahuan yang terdiversifikasi tentang diversifikasi pasar saham, hasil menunjukkan bahwa membangun pemahaman yang lebih baik tentang pasar saham mungkin menjadi salah satu target kebijakan penting untuk meningkatkan literasi keuangan kelas menengah di negara-negara berkembang [10]. Sebagai jalan untuk penelitian di masa depan, pertanyaan yang relevan adalah apakah meningkatkan literasi keuangan kelas menengah dalam pengembangan negara memiliki manfaat di luar peningkatan kesejahteraan individu. berharap bahwa literasi keuangan merupakan komponen penting dalam tiga dari lima saluran meskipun perkembangan keuangan mengarah pada pertumbuhan mobilisasi tabungan yang lebih efisien, manajemen risiko yang lebih baik dan meningkatkan pertukaran barang dan jasa. Studi lintas negara dapat menyelidiki potensi manfaat ekonomi makro ini.

Penelitian Kapoor dan Prosad pada tahun 2017 [11] mengkaji perkembangan dalam perilaku keuangan melalui perjalanan sejarah keuangan. Ini memberikan bukti paling awal dari kelainan perilaku yang dilaporkan oleh para peneliti di pasar saham. Ini memulai diskusi dengan keuangan tradisional diikuti dengan analisis teori tradisional dalam situasi di mana mereka dianggap tidak mencukupi. Penelitian ini kemudian menyoroti pentingnya Perilaku keuangan dan posisinya yang unik dalam menjembatani kesenjangan antara situasi kehidupan nyata dan teoriteori tradisional. Perilaku keuangan berhubungan dengan jiwa investor dan perannya dalam pengambilan keputusan keuangan. Bidang ini melonggarkan asumsi rasionalitas hadir dalam teori keuangan standar dan menjelaskan bahwa investor nyata dipengaruhi oleh bias psikologis mereka. Bias-bias ini diterjemahkan ke dalam perilaku mereka sehingga mereka dapat mengambil keputusan yang tidak optimal. Keputusan semacam itu, dalam skala besar, dapat menyebabkan gangguan di pasar dan dikenal sebagai anomali pasar. Karena, anomali semacam itu memiliki dampak buruk pada kesehatan keuangan individu maupun kesehatan keuangan seluruh ekonomi, mereka perlu dicegah. Pencegahan seperti itu hanya dapat terjadi dengan meningkatnya kesadaran para praktisi tentang keterbatasan psikologis dan perilaku mereka [12]. Oleh karena itu, analisis yang lebih mendalam tentang bidang ini sangat penting di zaman sekarang.

Untuk meningkatkan pemahaman tentang bagaimana orang membuat keputusan keuangan, penting untuk menyelidiki karakteristik psikologis apa yang memengaruhi perilaku finansial dan kesejahteraan finansial individu yang positif. Dalam penelitian [4], mengeksplorasi pengaruh perbedaan individu dalam pengendalian diri dan faktor nonkognitif lainnya pada perilaku keuangan dan kesejahteraan finansial. Orang dengan kontrol diri yang baik lebih cenderung menghemat uang dari setiap cek pembayaran, memiliki perilaku keuangan umum yang lebih baik, merasa kurang cemas tentang masalah keuangan, dan merasa lebih aman dalam situasi keuangan mereka saat ini dan di masa depan [13].

\section{METODE PENELITIAN}

Penelitian ini menggunakan metode kajian pustaka dengan memabandingkan beberapa hasil penelitian terdahulu yang relevan pada permasalahan pandemik global saat ini. Penelitian ini mendeskripsikan hasil penelitian mengenai perilaku keuangan dimulai dari tahun 2012 hingga 2020 serta dikaitkan dengan permasalahan pandemic COVID-19 yang sedang dihadapi Indonesia. 


\section{HASIL DAN PEMBAHASAN}

Wabah COVID-19 yang sedang berlangsung menghasilkan liputan berita yang belum pernah terjadi sebelumnya dan curahan pendapat di era penyebaran informasi yang cepat ini. [14] menganalisis hubungan antara sentimen yang dihasilkan oleh berita terkait COVID-19 dengan volatilitas pasar ekuitas. Ketidakpastian di pasar keuangan menyebabkan peningkatan volatilitas harga dan kepanikan luar biasa yang ditimbulkan oleh outlet berita terkait dengan peningkatan volatilitas di pasar ekuitas. Hasil penelitian untuk sektor ekonomi individu menunjukkan bahwa berita panik-sarat berkontribusi pada tingkat yang lebih besar terhadap volatilitas di sektor yang dianggap paling terpengaruh oleh wabah virus coronavirus. Wabah terbaru (COVID-19) telah mengumpulkan banyak perhatian dari outlet media di seluruh dunia. Media yang melaporkan cenderung mengarah ke menyoroti peristiwa berdampak tinggi seperti wabah penyakit menular yang menyebabkan kepanikan publik. Berita yang terkait dengan penyakit menular dapat menyebabkan kekhawatiran dan memengaruhi sentimen investor. Wabah COVID-19 baru-baru ini berdampak pada hampir semua negara. Pasar AS dan pasar dunia yang serupa telah mengalami penurunan hampir 30\% dalam kuartal pertama 2020. Pada saat akses berita dan informasi yang belum pernah terjadi sebelumnya, individu (termasuk investor) merasa sulit untuk secara akurat menilai signifikansi ekonomi dan dampak dari dampak tersebut. informasi. Menggunakan bukti dari literatur psikologi, Barberis et al. (1998) menunjukkan bahwa pasar keuangan bereaksi berlebihan terhadap pola berita yang konsisten, meskipun secara statistik bobot berita tersebut harus rendah. Studi sebelumnya mengungkapkan hubungan lemah atau moderat antara kuantum berita dan aktivitas (volume, volatilitas, harga) di pasar keuangan (mis. Mitchell dan Mulherin, 1994; Berry dan Howe, 1994). Namun, Ederington dan Lee (1994), mengamati bahwa pengumuman berita ekonomi makro terjadwal menjelaskan sebagian besar dari volatilitas di pasar keuangan. Klibanoff et al. (1998) juga menemukan bukti reaksi pasar yang berlebihan terhadap keunggulan berita dalam konteks reksa dana ujung tertutup. Ketika dunia menjadi lebih terhubung dan arus informasi menjadi hampir seketika, penggunaan komputer dan kecerdasan buatan untuk membaca, menafsirkan dan membuat keputusan keuangan berdasarkan berita menjadi strategi perdagangan yang layak [15]. Ada juga penelitian yang menemukan sentimen berita yang berguna untuk alokasi aset oleh manajer portofolio. Literatur penetapan harga aset telah menggali variabel suasana hati dalam mencoba menjelaskan perilaku pasar [16] dan memperluas aliran literatur ini dengan kecenderungan khusus pada krisis kesehatan dengan mengeksplorasi apakah media melaporkan covid-19, panik di kalangan investor, dan sentimen global telah berperan dalam volatilitas yang sebelumnya tak terlihat di pasar ekuitas [17]. Literatur sebelumnya berpendapat bahwa pelaporan yang tidak seimbang dari krisis perawatan kesehatan mengarah ke perpecahan dalam risiko aktual versus risiko yang mengarah pada reaksi sentimen yang berlebihan. Selanjutnya Penelitian ini menambah literatur yang saat ini sedikit tentang memahami reaksi pasar saham terhadap pandemi covid-19.

Penelitian ini memperluas literatur pada tiga dimensi [18]. Pertama itu menambah literatur yang berkembang tentang respons pasar terhadap pandemic. Kedua memfokuskan analisis pada tingkat sektor, menambah literatur heterogenitas di pasar keuangan Pesan keseluruhan yang berasal dari literatur ini menunjukkan bahwa sektor dan saham adalah heterogen, dan analisis tingkat indeks agregat mengasumsikan homogenitas dalam pengembalian pasar saham dan profil volatilitas. Dimensi ketiga dari literatur di mana Penelitian ini berkontribusi adalah dampak dari liputan media yang berasal dari sentimen kepanikan di pasar keuangan [19]. Di era informasi ini, pandemi seperti korporasi yang sedang berlangsung wabah COVID-19 menyebabkan kegilaan media dan persaingan untuk berita 'melanggar' terbaru di outlet media. Partisipasi di pasar keuangan mungkin tidak dengan cepat dan akurat menilai dampak ekonomi dari gempuran berita semacam itu.

Penelitian [18] telah mempertimbangkan bahwa investor berperilaku rasional, dan mengabaikan untuk memasukkan ke dalam model ekonomi makro kognitif dan kelemahan emosional yang dapat mempengaruhi perilaku investor. Teori keuangan mengandaikan bahwa pasar efisien dan bahwa jika ketidakefisienan pasar mungkin ada, mereka umumnya tidak mudah dieksploitasi. Dalam kerangka kerja ini, bukti tidak mendukung kemampuan investor untuk melakukan pasar atau menghasilkan pengembalian abnormal. Bukti teoretis dan empiris menunjukkan bahwa 
pengaruh psikologis sangat penting dalam pengambilan keputusan. Investor rentan terhadap faktor psikologis yang mendorong perilaku mereka dan mempengaruhi keputusan mereka di tingkat pasar keuangan. Menggunakan data untuk 5 pasar saham internasional, temuan menunjukkan pertama bahwa hipotesis sesuai dengan yang investor jalankan secara rasional harapan gagal menjelaskan cara ekonomi bekerja [20]. Peningkatan volume perdagangan sebagian besar diamati di pasar internasional utama di negara-negara maju tidak dapat disebabkan oleh kehadiran investor rasional mutlak. juga menemukan bahwa ekonomi didorong oleh bias perilaku, termasuk terutama roh hewan. Di pasar utama yang telah pelajari, peningkatan volume perdagangan yang disebabkan oleh adanya investor yang optimis, pesimistis serta investor dengan reaksi spontan [21]. Namun, ada dua kekhasan yang menjadi ciri pasar Jepang dan Prancis. Pada awalnya, fluktuasi volume perdagangan disebabkan oleh adanya investor yang terlalu percaya diri dan lebih optimis. Dalam oposisi, kehadiran investor yang lebih pesimistis sangat mempengaruhi evolusi perdagangan dalam kasus spesifik pasar Prancis [1].

Sementara penelitian [19] menyajikan mayoritas teori dan model keuangan klasik didasarkan pada asumsi perilaku investor yang rasional di pasar mengenai bisnis modern, berfokus pada kegiatan yang bertanggung jawab secara sosial ditentukan oleh tren umum, di mana individu dan perusahaan bisnis menyadari tanggung jawab mereka terhadap semua mereka yang dipengaruhi oleh hasil dari kegiatan mereka. Penelitian yang dilakukan telah membuktikan bahwa ketika membuat keputusan di bawah kondisi ketidakpastian dan risiko, orang mengalami efek dari berbagai ilusi, emosi, persepsi informasi yang keliru dan faktor "irasional" lainnya. Tanggung jawab sosial perusahaan mencerminkan peran baru bisnis dalam masyarakat [20]. Baru-baru ini, tradisi tanggung jawab sosial perusahaan telah mulai menyebar cukup cepat baik di perusahaan internasional besar dan perusahaan kecil dan menengah. Penyebaran ide bisnis yang bertanggung jawab secara sosial telah mendorong perlunya berinvestasi di perusahaan yang menerapkan praktik bisnis semacam itu [19].

Selama bertahun-tahun, keuangan tradisional selalu beranggapan bahwa investor rasional dalam proses pengambilan keputusan mereka di pasar saham tentang trade-off pengembalian risiko dan memaksimalkan utilitas. Namun, studi Perilaku keuangan mengungkapkan bahwa manusia tidak berperilaku seasional yang diperkirakan oleh para ekonom karena keputusan mereka terkadang dipengaruhi oleh perasaan psikologis mereka. Sejumlah penelitian dari ASEAN, Timur Tengah dan negara-negara Barat sebenarnya telah menetapkan bahwa faktor-faktor psikologis memiliki hubungan dan dampak pada pengambilan keputusan investor di pasar saham mereka. Sehubungan dengan ini, penelitian ini mencoba untuk menjembatani kesenjangan perbedaan dalam hal lokasi geografis dan profil demografis antara Malaysia dan negara-negara lain dengan meneliti dampak faktor psikologis terhadap pengambilan keputusan investor di pasar saham Malaysia. Kuisioner dibagikan kepada sampel sejumlah 200 investor di wilayah Klang Valley dan Pahang yang berusia antara 18-60 tahun yang terlibat dalam pasar saham Malaysia. Temuan menunjukkan bahwa kepercayaan yang berlebihan, konservatisme, dan bias ketersediaan memiliki dampak signifikan pada pengambilan keputusan investor sementara perilaku menggembalakan tidak memiliki dampak signifikan pada pengambilan keputusan investor. Juga ditemukan bahwa faktor psikologis tergantung pada jenis kelamin individu. Hasil penelitian [17] sebagian besar konsisten dengan bukti dalam penelitian sebelumnya. Studi ini, semoga, akan membantu investor untuk menyadari dampak dari faktor psikologis mereka sendiri pada pengambilan keputusan mereka di pasar saham, sehingga meningkatkan rasionalitas keputusan investasi untuk meningkatkan efisiensi pasar [7].

Wamae (2013) telah menyelidiki faktor-faktor perilaku yang mempengaruhi keputusan investasi di pasar saham Kenya fokus pada bank investasi. Faktorfaktor perilaku yang diselidiki adalah menggiring, mencari calon pelanggan, penghindaran risiko dan penahan. Dia menemukan bahwa semua faktor mempengaruhi keputusan investasi, dengan menggembalakan memiliki dampak paling besar, diikuti oleh pencarian calon, penjangkaran dan akhirnya faktor penghindaran risiko memiliki dampak paling kecil [21]. Bashir et al. (2013) mempelajari bias perilaku termasuk terlalu percaya diri, konfirmasi, dan ilusi kontrol, penghilangan kerugian, akuntansi mental, status quo dan optimisme berlebihan pada pengambilan keputusan keuangan investor. Studi ini menemukan bahwa ada hubungan positif yang signifikan dan dampak dari kepercayaan yang berlebihan, ilusi kontrol, bias konfirmasi dan optimisme berlebihan pada pengambilan keputusan investor. Juga ditemukan bahwa status quo, keengganan kerugian dan bias akuntansi mental memiliki hubungan yang signifikan tetapi tidak 
berdampak pada pengambilan keputusan investor. Nofsingera dan Varmab (2013) melihat bias ketersediaan pada pengambilan keputusan dengan mengeksplorasi bagaimana heuristik ketersediaan dapat mengarahkan investor untuk fokus pada saham yang dikenal, termasuk yang dia miliki beberapa kali (dibeli kembali). Menggunakan informasi saham yang terdaftar di NYSE, AMEX dan NASDAQ, mereka menemukan bahwa efek resensi yang merupakan bentuk bias ketersediaan dalam penjualan saham memainkan peran yang mendalam dan dominan dalam perilaku pembelian kembali ini. Analisis mereka juga mengungkapkan bahwa bahkan di hadapan lingkungan yang lebih besar untuk perdagangan informasi, dampak bias ketersediaan pada keputusan pembelian kembali tetap kuat. Babajide dan Adetiloye (2012) melakukan studi empiris tentang bias perilaku investor di Nigeria pasar keamanan. Studi ini menemukan bukti kuat bahwa terlalu percaya diri, penolakan, pembingkaian dan bias status quo ada di antara investor Nigeria. Hubungan negatif yang lemah antara bias dan kinerja pasar saham juga terbentuk. [22].

\section{KESIMPULAN DAN SARAN}

Dampak pandemi COVID-19 terus berkembang di seluruh dunia, ini memengaruhi orang dan komunitas yang berbeda dengan cara yang berbeda. Banyak penelitian yang menganalisis Perilaku keuangan perusahaan telah dilakukan dalam beberapa dekade terakhir. Perilaku keuangan penting di tingkat individu maupun perusahaan. Biasanya sebagian besar penelitian perilaku perusahaan terkait dengan struktur modal, penganggaran atau masalah keuangan.

\section{REFERENSI}

[1] D. Jurevičienè, E. Bikas, G. KeliuotytèStaniulėnienè, L. Novickyte, and P. Dubinskas, "Assessment of Corporate Behavioural Finance," Procedia - Soc. Behav. Sci., vol. 140, pp. 432-439, 2014, doi: 10.1016/j.sbspro.2014.04.449.

[2] Y. Fan, "Does adversity affect long-term financial behaviour? Evidence from China's rustication programme," J. Urban Econ., vol. 115, no. November 2019, 2020, doi: 10.1016/j.jue.2019.103218.

[3] A. Grohmann, "Financial literacy and financial behavior: Evidence from the emerging Asian middle class," Pacific Basin Financ. J., vol. 48, no. July 2017, pp. 129-143, 2018, doi: 10.1016/j.pacfin.2018.01.007.

[4] C. Strömbäck, T. Lind, K. Skagerlund, D. Västfjäll, and G. Tinghög, "Does self-control predict financial behavior and financial wellbeing?," J. Behav. Exp. Financ., vol. 14, pp. 3038, 2017, doi: 10.1016/j.jbef.2017.04.002.

[5] S. McNair, B. Summers, W. B. de Bruin, and R. Ranyard, "Individual-level factors predicting consumer financial behavior at a time of high pressure," Pers. Individ. Dif., vol. 99, pp. 211216, 2016, doi: 10.1016/j.paid.2016.05.034.

[6] F.-M. Toma, "Behavioral Biases of the Investment Decisions of Romanian Investorson the Bucharest Stock Exchange," Procedia Econ. Financ., vol. 32, no. 15, pp. 200-207, 2015, doi: 10.1016/s2212-5671(15)01383-0.

[7] E. Bikas, D. Jurevičienè, P. Dubinskas, and L. Novickyte, "Behavioural Finance: The Emergence and Development Trends," Procedia - Soc. Behav. Sci., vol. 82, pp. 870-876, 2013, doi: 10.1016/j.sbspro.2013.06.363.

[8] T. K. Hira, "Promoting sustainable financial behaviour: Implications for education and research," Int. J. Consum. Stud., vol. 36, no. 5, pp. 502-507, 2012, doi: 10.1111/j.14706431.2012.01115.x.

[9] J. Lopez-Gracia and C. Aybar-Arias, "An Empirical Approach to the Financial Behaviour of Small and Medium Sized Companies," Small Bus. Econ., vol. 14, no. 1, pp. 55-63, 2000, doi: 10.1023/A:1008139518709.

[10] S. Thomas, M. Goel, and D. Agrawal, "A framework for analyzing financial behavior using machine learning classification of personality through handwriting analysis," $J$. Behav. Exp. Financ., vol. 26, p. 100315, 2020, doi: 10.1016/j.jbef.2020.100315.

[11] S. Kapoor and J. M. Prosad, "Behavioural Finance: A Review," Procedia Comput. Sci., vol. 122, pp. 50-54, 2017, doi: 10.1016/j.procs.2017.11.340.

[12] N. Zhu, Y. Bu, M. Jin, and N. Mbroh, "Green financial behavior and green development strategy of Chinese power companies in the context of carbon tax," J. Clean. Prod., vol. 245, 2020, doi: 10.1016/j.jclepro.2019.118908.

[13] A. Sayinzoga, E. H. Bulte, and R. Lensink, "Financial Literacy and Financial Behaviour: Experimental Evidence from Rural Rwanda," Econ. J., vol. 126, no. 594, pp. 1571-1599, 2016, doi: 10.1111/ecoj.12217.

[14] O. Haroon and S. A. R. Rizvi, "COVID-19: 
Media coverage and financial markets behavior-A sectoral inquiry," J. Behav. Exp. Financ., vol. 27, p. 100343, 2020, doi: 10.1016/j.jbef.2020.100343.

[15] T. G. Seuntjens, N. van de Ven, M. Zeelenberg, and A. van der Schors, "Greed and adolescent financial behavior," J. Econ. Psychol., vol. 57, pp. 1-12, 2016, doi: 10.1016/j.joep.2016.09.002.

[16] N. Tang and A. Baker, "Self-esteem, financial knowledge and financial behavior," J. Econ. Psychol., vol. 54, pp. 164-176, 2016, doi: 10.1016/j.joep.2016.04.005.

[17] S. Bakar and A. N. C. Yi, "The Impact of Psychological Factors on Investors' Decision Making in Malaysian Stock Market: A Case of Klang Valley and Pahang," Procedia Econ. Financ., vol. 35, no. October 2015, pp. 319-328, 2016, doi: 10.1016/s2212-5671(16)00040-x.

[18] A. Dhaoui, "What Does Matter in Economy Today: When Human Psychology Drives Financial Markets," Arab Econ. Bus. J., vol. 10, no. $1, \quad$ pp. 39-47, 2015, doi: 10.1016/j.aebj.2014.12.002.

[19] A. Guzavicius, R. Vilke, and V. Barkauskas, "Behavioural Finance: Corporate Social Responsibility Approach," Procedia - Soc. Behav. Sci., vol. 156, no. April, pp. 518-523, 2014, doi: 10.1016/j.sbspro.2014.11.232.

[20] C. Oprean and C. Tanasescu, "Effects of Behavioural Finance on Emerging Capital Markets," Procedia Econ. Financ., vol. 15, no. 14, pp. 1710-1716, 2014, doi: 10.1016/s22125671(14)00645-5.

[21] M. Statman, "Behavioral finance: Finance with normal people," Borsa Istanbul Rev., vol. 14, no. 2, pp. 65-73, 2014, doi: 10.1016/j.bir.2014.03.001.

[22] M. Baddeley, C. Burke, W. Schultz, and P. Tobler, "Herding in Financial Behaviour: A Behavioural and Neuroeconomic Analysis of Individual Differences," Cambridge Work. Pap. Econ. 1225, no. May, p. Faculty of Economics, University of Cambridge, 2012. 